\title{
Towards ensuring inter-religious harmony in a multi-religious society of Perak
}

\author{
Mohd Ikhwan Izzat Zulkefli ${ }^{1, *}$, Mohd Nuri Al-Amin Endut ${ }^{1}$, Muhammad Ridhuan Tony \\ Lim Abdullah ${ }^{1}$, and Azizan Baharuddin ${ }^{2}$ \\ ${ }^{1}$ Department of Management and Humanities, Universiti Teknologi PETRONAS, 32610 Bandar Seri \\ Iskandar, Perak, Malaysia \\ ${ }^{2}$ Institute of Islamic Understanding Malaysia, 2, Langgak Tunku Off Jalan Tuanku Abdul Halim, \\ 50480 Kuala Lumpur, Malaysia
}

\begin{abstract}
Inter-religious harmony is crucial in maintaining political and national stability. Living in a peaceful and harmonious environment is important when the society consists of diverse races and religious adherents. The existence of minor tension in the society to some extent has jeopardised inter-religious relations. The failure to preserve religious harmony could expose the society to conflict and chaos. Thus, this paper aims to discuss and elaborate the pertinent elements in sustainable harmony among multi-religious society in Perak. The paper elaborates on the fundamental factors contributing to socio-religious harmony among multi-religious society. Library research method is used in addressing the situation of religious harmony in Perak and the pertinent element should be fostered in order to preserve religious harmony. This paper also emphasises that elements such as acceptance, understanding, co-operation as well as right and justice are significant elements in sustaining religious harmony. Hence, the discussion is aimed to build a sustainable concept of multi-religious harmony in Perak. The findings could also encourage multi-religious society to maintain and build a strong relationship among them.
\end{abstract}

Keywords: Religious harmony, the element of harmony, conflict, challenge, Perak

\section{Introduction}

Malaysia is one of the countries that has a pluralistic society in the region of Southeast Asia. It is a developing country that has 32.3 million population in 2017 (Malaysia, 2018) with various ethnicities and religious backgrounds. The Malaysian nation comprises of multiracial, multi-religious, multicultural, and multilingual society. Historically, the formation of Malaysia as a pluralistic country can be traced back to the Malay Sultanate of Malacca in the early fifteenth century (Ahmad, 2007). During that time, Malacca is one of

\footnotetext{
* Corresponding author: ikhwanmuslimin92@gmail.com
} 
the most strategic and famous centres of trade in the Malay Archipelago (Ahmad, 2007). Besides, this country has also been occupied by several western countries, namely, Portuguese, Dutch and British. On 31 August 1957, this country achieved independence from the British. Even though this country has reached her independence for over 6 decades, this country has been experiencing major and minor conflict of inter-religious adherents since its independence.

Religious harmony is crucial in ensuring unity and solidarity among multi-religious adherents. In 2017, Malaysia is placed as the twenty-ninth most peaceful country in the world and the fifth most peaceful country in the region of Asia Pacific (Peace, 2017 ). However, it is not immune from inter-religious conflict whereby it could interrupt social relation and national stability (Abdullah et al., 2016). The conflict between religious adherents is an inevitable issue which could become a great challenge for the government, religious leaders as well as society to preserve social harmony among the Malaysian communities. As emphasised by Sintang, Baharuddin, and Khambali (2012), they stated that the government faced a challenge to create religious harmony and peaceful environment among multi-religious adherents. It is very important for the government to manage every inter-religious conflict wisely in order to avoid it from becoming worse (Samad, 2016). Hence, strengthening unity and solidarity among multi-religious adherents is considered as a major instrument to ensure social harmony and peaceful co-existence in the society.

In maintaining inter-religious harmony, the government plays an important role by enforcing various efforts and policies. There are a number of programmes, activities and policies that have been invented by the government to ensure all Malaysian society with different ethnic and religious backgrounds to mingle with each other (David, McLellan, Meng, Li, \& Tien, 2010). Preserving social harmony has become a national agenda for the government since the past decades. It is important to note that religious harmony is vital in preserving inter-religious relations. Among government efforts to preserve a harmonious society are the implementation of Rukun Negara (National Principles), 1 Malaysia Concept, the formation of the Department of National Unity of Integration (JPNIN), Institute for Ethnic Studies (KITA) (Abdullah, Al-Amin, Ur-Rahman, Baharuddin, \& Ahmad, 2017), and the celebration of religious festivals (Bakar, 2013), to name a few. Therefore, this paper is aimed to discuss and elaborate the pertinent elements in sustainable harmony among multi-religious society in Perak.

\section{The background of multi-religious society in Perak}

The formation of Perak as a multi-racial and multi-religious society began when the Chinese and Indian residents were granted full citizenship. Perak is one of the thirteen states of Malaysia and the fourth largest state in the country. This state consists of three main ethnic groups namely, Malay, Chinese, Indian and followed by other ethnic groups. Religious diversity is a main characteristic of Perak because its population comprises of heterogeneous religions and ethnicities.

Furthermore, every ethnic group in Perak has their own identities and backgrounds in terms of languages, cultures as well as customs and beliefs system. With the diversity of religion, race, language, and culture, Perak has shaped its own cultural identity as a multicultural state. Almost all major world religions exist in this state namely Islam, Buddhism, Hinduism, Christianity, Confucianism, and Taoism. Today, Perak's population is estimated to be at about 2,496.4 million people with $56.4 \%$ Bumiputera, $27.9 \%$ Chinese, $11.2 \%$ Indian and $0.4 \%$ others. Meanwhile, the total population of non-Malaysian citizens is $4.1 \%$ (Malaysia, 2018 ). In terms of religious adherents, Islam recorded the highest percentage of religious adherents at $55.3 \%$, followed by Buddhism at $25.4 \%$, Hinduism at $10.9 \%$, 
Christianity at $4.3 \%$, Confucianism, Taoism and Tribal/folk/other traditional Chinese religion took $1.7 \%$ and other religions being at $0.8 \%$ (Malaysia, 2010).

Historically, the formation of Perak as a multi-ethnic and multi-religious society was closely associated to the large-scale migration of workers and labourers from mainland China and India to the Malay Archipelago in the nineteenth century (Mun, 2013). According to Jamil (2010), the Malay Archipelago was mainly mono-ethnic inhabited by the Malays in early nineteenth century. However, between 1874-1957, there was a great social landscape change of Malaysian society from homogenous into heterogeneous society during British colonisation (Jamil, 2010). The major factor has led the British to bring Chinese and Indian labourers to the Malay Archipelago due to the need of workers to work in tin mines, plantations, and estates (Mun, 2013). Thus, the migration of Chinese and Indians from their countries is a main factor that formed Perak as a multi-religious society in nowadays.

It is important to emphasise that the existence of diverse religious adherents in Perak is one of the challenges for the government and society in order to retain peace and harmony. Although Perak seems like a peaceful state, the emergence of conflicts in Perak has a great potential to interrupt national and political stability. Sintang et al. (2012) highlighted that inter-religious issues and incidents became more complicated when it deals with the issues of living together and social interaction rather than dealing with the theological issues. Nowadays, there are numerous religious conflict cases especially those related to the place of worship, the right of child custody (Ahmad, Talib, Isa, Gill, Jawan \& Mohad, 2014) and the issue of kalimah Allah which can be used by non-Muslim (Nor, 2011). Besides that, other sensitive issues related to religious matters include the use of Quranic and Arabic terminologies, Islamic propagation, funeral process, and the use of halal certificate by nonMuslim businessman (Sintang et al., 2012). Thus, it is clearly showed that religious issues nowadays are no longer dealing with the theological aspect of religion.

\section{Religious harmony in Perak}

As a multi-religious state, Perak is a peaceful and harmonious state in Malaysia. In order to create a harmonious society, a lot of efforts should be implemented to maintain peaceful coexistence. The Sultan of Perak, Sultan Nazrin Shah asserts that "Malaysians were from different races and practised different religions and cultures, hence building harmony in the country is a collective responsibility" ("Sultan Nazrin: respect religious boundaries to maintain peace and harmony," June 12, 2014). This shows that preserving and creating peaceful coexistence is a collective responsibility among government, religious leaders, and society. There are numerous efforts enforced by the government and non-governmental organisation (NGOs) in order to build inter-religious harmony. Among the initiatives are inter-religious dialogue, 1 Malaysia concept and the formation of the Department of National Unity of Integration (JPNIN).

However, religious harmony in Perak has also been disturbed by minor tension or conflict. There are several incidents that could interrupt inter-religious relations in Perak. There was an incident at Jalan Hospital Ipoh where a man went to the Sree Muneeswaran Amman Kovil Temple and broke the statues (Zahari, 2016). The statues in the Hindu temple are considered as sacred among the Hindus and such incident were regarded as an insult to their religion. This incident has created a tense situation and anger among Hindus. Besides, there was also the issue of Taiping MP who wished Hari Raya celebration featuring a picture of US flag (Fai, 2016) and a caricature of giving out cash in the form of "duit Raya" to children and guest during Hari Raya as a bribe (Ghazali, 2016). These issues have been regarded as insulting the noble practice of Muslim community in Malaysia. The 
implications of the incidents pertaining to religious tension could lead to hostility and enmity between religious adherents.

Furthermore, the case of conversion of three children to Islam by their father Mohd Ridzuan Abdullah could also jeopardise inter-religious relations. The main issue in this case is the father who is a Muslim attempted to convert his children to Islam without the knowledge of their mother who is a Hindu. However, the mother named Indira Gandhi applied for judicial review in the High Court of Ipoh because the certificates of conversion of her three children to Islam is inconsistent with section 106 (b) of the Islamic Administration Religious Enactment of Perak 2004 and section 5 and 11 of the Guardianship of Infant Act 1961 (Kusrin, Hamjah, \& Sham, 2015). In 2018, the Federal Court declared that the conversion of these three children to Islam is null and void (Karim, January 29, 2018). Based on these issues and incidents, it shows that religious issue is a sensitive matter that should be resolved wisely. Even the smallest of incident could spread very fast and become a trigger to the immense incident. Therefore, to those living in a multi-religious society, respecting other religious adherents is significant to preserve interreligious relationship.

\section{Fundamental elements of sustaining religious harmony}

\subsection{Acceptance}

A multi-religious society is a community with diverse religions such as Islam, Buddhism, Hinduism, Christianity and others. In order to live in a peaceful and harmonious society, acceptance of other religious adherents in a particular community is very important. In Islamic perspective, Islam is a religion that accepts the diversity of religions in this world but rejects that all religions are of truth. Religious plurality can be defined as the diversity of religion in this world. However, in the concept of religious pluralism, it can be defined as a belief that all religions in this world is absolute truth (Sintang, 2014). Pluralist viewed that all religion in this world is true and should be respected. For John Hick, he accepts the understanding that all truth claims are valid and then should be given equal respect and it only means that the Christian has to accept other truth claims such as Muslims, Jews, Hindus and others (Sintang, 2014). However, in Islamic perspective, Islam accepts the diversity of religions but it does not recognise all religions as truth.

Moreover, acceptance of different religious background among multi-religious society is a key to ensuring harmony and solidarity in the country (Talib, Gill, \& Ramli, 2014). Appreciation of the religious diversity in a multi-religious society is an essential factor in maintaining social harmony. This is in line with Abdullah et al. (2016), where appreciating kindness and common values of other religions is among the important elements in maintaining harmony. For example, Muslim people appreciating the existence of other religious groups such as Buddhist, Hindus, and Christians can strengthen inter-religious relationship and nurture kindness towards them. Therefore, accepting and appreciating the existence of religious diversity should be regarded as a binding factor of the particular community.

\subsection{Understanding}

Every individual who lives in a multi-religious society should understand and accept religious diversity. Understanding of the faith and teachings of other religious groups could encourage an individual to accept and respect the beliefs of others religions. According to Rahman and Khambali @ Hambali (2013), the celebration of all religions in Malaysia is a 
sign of respecting the existence of multi-religious adherents in Malaysia as stated in the concept of 1 Malaysia. However, when the community in Malaysia do not understand the faiths of other religions it could contribute to the misunderstanding of concept of religious tolerance (Rahman \& Khambali @ Hambali, 2013).

The concept of mutual understanding seems vital as people should not interrupt the practices of other religious adherents (Kasmo, Usman, Taha, Salleh, \& Alias, 2015). Every individual or religious adherents should respect the doctrines of other religions. Mutual respect among inter-religious adherents is also considered as an important principle to preserve a harmonious society in Malaysia (Abdullah et al., 2016). Respecting the existence of religious diversity can contribute to political and national stability. Attitudes of respect could also improve inter-religious relations by acknowledging the existence of multireligious groups. The value of mutual respect, cooperation, tolerance, understanding, and goodwill are the significant elements to be practised while living in a multi-racial and religious society (Seok et al., 2013).

\subsection{Co-operation}

The element of co-operation is also important to build good relationship among multireligious adherents. With the existence of this element in their life, they will respect and tolerate other religious adherents. Co-operation can be seen through their action by respecting the celebrations, rituals as well as beliefs of other religious adherents in their community. Hence, every individual living in a multi-faith society should tolerate and cooperate with each other. The Theory of 'Asabiyah by Ibn Khaldun emphasised that 'Asabiyah (spirit of kinship within the family or tribe) is important in order to strengthen the relationship among individual in the community. Ibn Khaldun viewed 'Asabiyah from positive side. Moreover, Ibn Khaldūn emphasised that the spirit of 'Asabiyyah basically exists due to the primitive life possessed by certain groups or nations when they face difficulties (Halim, Nor, Ibrahim, \& Hamid, 2012). When these groups or communities face difficulties, this will force them to stand together and protect their people from any harm from outside the group (Halim et al., 2012). The feeling of 'Asabiyyah also can lead people to protect and improve their group or society towards a better nation. The spirit of 'Asabiyyah can also emerge as a solidarity within large group anonymous (Halim et al., 2012).

\subsection{Right and Justice}

In order to preserve a harmonious society, the right and freedom in practising religions should be given to all multi-religious adherents. The right and freedom of every religious adherents should not be abandoned (Abdullah et al., 2016). The right and freedom of practising religion is a basic human right for each individual and it should not be neglected. However, in Malaysia, defining the rights of Muslim and non-Muslim is still not clear (Rahman \& Khambali @ Hambali, 2013). The vagueness of the civil and Shariah court jurisdiction has contributed to the problems of conversion of religions. The overlapping of the civil and Shariah court jurisdiction contributes to the difficulties to solve the case.(Rahman \& Khambali @ Hambali, 2013).

In Malaysian context, the right of practising a religion is mentioned in the Federal Constitution of Malaysia. This is based on Article 3 (1), "Islam is the religion of the Federation; but other religions may be practised in peace and harmony in any part of the Federation" (Federal Constitution of Malaysia 2010). Based on this provision, it can be understood that Islam is declared as an official religion in Malaysia and specifically in Perak. However, at the same time, other religious adherents were also given freedom to 
practise their beliefs in this country. In addition, Article 11 (1) also declared that "every person has the right to profess and practise his religion and, subject to Clause (4), to propagate it" (Federal Constitution of Malaysia 2010). Based on this article, it is also mentioned that all religious adherents can practise their understanding but they cannot propagate their beliefs to Muslim. This showed that the right and freedom should be given in sustaining peaceful and harmonious society.

In addition, Islam always empahsised on the concept of justice ( $a l$ - 'adl). The term 'justice' may refer to "administration of law according to prescribed and accepted principles, conformity to the law, legal validity the quality or fact of being just" (Ismail, 2015). In Islam, it is important to emphasise the concept of justice. Islam emphasises on justice towards inter-personal relationships within the family, within the community, in the interaction between communities and nations, in the interface between the human being and nature (Qur'an, 4: 58, 65,105,135). There is justice to kith and kin, to the orphan, to the destitute, to the slave, to the wayfarer, to the needy (Qur'an, 2: 177). Justice is to bond and hold society together and transforms it into one brotherhood (Ismail, 2015). In order to have justice in harmony, the right to practise religion by an individual or religious group should be permitted.

\section{The challenges of religious harmony}

It is important to note that living in a harmonious society without conflict and tension is very important. No single person in this world would prefer to live in tension, conflict, and war. Thus, strengthening unity and solidarity among religious adherents is essential to create a harmonious society. Inter-religious harmony should be built based on trust and mutual respect among multi-religious adherents. The existence of harmony could prevent any conflict which contributes to fragility of inter-religious relations and political instability.

However, there are various challenges to improve and strengthen the relationship between multi-religious adherents. The disagreement between religious adherents happened due to the lack of mutual respect. Mutual respect among inter-religious adherents are crucial nowadays to strengthen the relationship between different religious adherents. Based on the study conducted by Abdullah et al. (2016), the study highlighted that mutual respect is considered as an important element to build a good relationship between religious adherents. It is also very significant to be practiced, especially in daily interaction. Meanwhile, Rahman and Khambali@ Hambali (2013) asserts that people should not only respect the doctrines of religions but also should respect the adherents of the respective religions. Social interaction and communication between different religions are essential to guarantee a harmonious society. Besides, a study conducted by Talib et al. (2014) also emphasized that all people should respect the doctrine and teaching of other religious adherents. Mutual respect in this context is that all religious adherents such as Muslim, Buddhist, Hindu, and Christian should respect each other, specifically in the aspect of belief or doctrine, teaching, and festival.

Furthermore, the study shows that inter-religious conflict also happens due to the issue of right and freedom of religion. Freedom of religion is applied to all religious adherents regardless of Muslim and non-Muslim. Based on article 11 (1), the Constitution of Malaysia declared that "Every person has the right to profess and practise his religion" (Federal Constitution of Malaysia 2010). Through this provision, it is highlighted that all religious adherents have an equal right to practise their doctrines. However, other religious adherents such as Christian and Hindu is not allowed to disseminate their faith towards Muslim. This is based on Article 11 (4) "State law and in respect of the Federal Territories of Kuala Lumpur, Labuan, and Putrajaya, federal law may control or restrict the 
propagation of any religious doctrine or belief among persons professing the religion of Islam" (Federal Constitution of Malaysia 2010). The restriction is imposed on all other religious groups except Islam. Although other religious adherents are guaranteed their rights but there are several of restriction imposed on them. This restriction also contributed to the tension. The minority group starts to question the privilege granted to Islam and Muslim. Khambali@ Hambali and Haled (2008) mentioned that issues related to freedom of religion should be discussed openly because all religious adherents are not facing any discrimination in terms of ethnic group and religion.

Besides that, maintaining harmony in the society is also a challenge when there is no clear guidance of tolerance practise. In this issue, there is no clear guideline and rule which describes the right of Muslims and non-Muslims (Rahman \& Khambali @ Hambali, 2013). This issue occurred when it is related to the conversion of religion from Islam to other religions. Rahman and Khambali @ Hambali (2013) stated that enactments of law is difficult to make due to the overlapping of the jurisdiction of court between civil and Shariah on certain issues. The ambiguity of laws would hence contribute to tension.

\section{Conclusion}

This paper presented that there are several minor issues which could jeopardise interreligious relations in Perak. The situation of religious harmony in Perak has also been discussed in order to show that there is tension although it is not as serious as other states in Malaysia. In addition, creating and ensuring a harmonious co-existence is the main agenda for the government and society. The government has implemented various efforts and policies to maintain religious harmony.

The occurrence of religious conflict had begun since Malaysia achieved its independence in 1957. Among religious issues that has always been discussed are religious conversion, the use of kalimah Allah, and the construction of worship places. However, there are various challenges in ensuring religious harmony such as lack of mutual respect, the abuse of rights and freedom of minority group. As a conclusion, apart from discussing the current situation of religious harmony in Perak, this paper also discussed the fundamental factors contributing to religious harmony. Among the important elements are acceptance, understanding, co-operation, as well as right and justice. These elements are important to strengthen inter-religious relations as well as building a harmonious coexistence.

This paper was financially supported by the Institute of Islamic Understanding Malaysia (IKIM).

\section{References}

Abdullah, M. R. T. L., Al-Amin, M. N., Ur-Rahman, A., Baharuddin, A., \& Ahmad, Z. (2017). Sustainable socio-religious harmony development in Malaysia: An interpretive structural modelling for multi-religious society Journal of AlTamaddun, 12(1), 53-64.

Abdullah, M. R. T. L., Al-Amin, M. N., Yusoff, A., Baharuddin, A., Khir, F. A., \& Talib, A. T. (2016). Socio-religious harmony index instrument indicators for Malaysia Journal of Al-Tamaddun, 11(2), 29-44.

Ahmad, Z. (2007). Multiculturalism and religio-ethnic plurality: the Malaysian experience. Culture and Religion, 8(2), 139-153.

Ahmad, Z., Talib, A. T., Isa, N. A. M., S.Gill, S., Jawan, J., \& Mohad, A. H. (2014 ). Tahap kepentingan isu-isu antara agama di Malaysia. Paper presented at the Seminar 
Antarabangsa Dakwah \& Etnik 2014: Da'wah \& Ethnicity: Multidisciplinary Perspective, Pusat Kajian Dakwah Orang Asli dan Pribumi, UKM, Bangi, Selangor. .

Bakar, I. A. (2013). The religious tolerance in Malaysia: an exposition. Advances in Natural and Applied Sciences, 7(1), 90-97.

David, M. K., McLellan, J., Meng, N. Y., Li, L. M., \& Tien, W. Y. M. (Eds.). (2010). Ethnic relations and nation building: the way forward. Petaling Jaya: Strategic Information and Research Development Centre (SIRD).

Federal Constitution of Malaysia (2010). The Commissioner of Law Revision, Malaysia.

Halim, A. A., Nor, M. R. M., Ibrahim, A. Z. B., \& Hamid, F. A. F. A. (2012). Ibn Khaldun's Theory of 'Asabiyyah and Its Application in Modern Muslim Society. Middle-East Journal of Scientific Research, 11(9), 1232-1237.

Ismail, K. (2015). Islam and the Concept of Justice. Jurnal Intelek, 5(2).

Jamil, H. (2010). Historical overview of Malaysia's experience in enhancing equity and quality of education: focusing on management and mediation of multiethnic issues. Paper presented at the Africa-Asia Experience Sharing Seminar: Efforts towards Improving the Quality of Education, Accra: Ghana.

Karim, K. N. (January 29, 2018). Indira Ghandi wins 9-year legal battle to nullify children's conversion to Islam by ex-husband. New Straits Times Retrieved from https://www.nst.com.my/news/crime-courts/2018/01/329967/indira-ghandi-wins9-year-legal-battle-nullify-childrens-conversion

Kasmo, M. A., Usman, A. H., Taha, M., Salleh, A. R., \& Alias, J. (2015). Religious tolerance in Malaysia: A comparative study between the different religious groups. Review of European Studies, 7(3), 184-191.

Khambali@ @ambali, K. M., \& Haled, M. H. M. (2008). Toleransi beragama dan amalannya di Malaysia: rujukan kepada artikel 11 perlembagaan persekutuan Malaysia. Jurnal Usuluddin, 27, 81-92.

Kusrin, Z. M., Hamjah, S. H., \& Sham, F. M. (2015). Muslim father's rights in determining his minor child's conversion to Islam in Malaysia. European Journal of Social Sciences Education and Research, 4(1), 15-21.

Malaysia, D. o. S. (2010). Total population by ethnic group, religion, sex and state, Malaysia, 2010.

Malaysia, D. o. S. (2018). Demographic statistics fourth quarter (Q4) 2017, Malaysia. Retrieved from https://www.dosm.gov.my/v1

Malaysia, D. o. S. (2018 ). Population by age group, sex and ethnic group, Perak, 2018.

Mun, C. Y. (2013). Ethnic socialization: A case of Malaysian Malay and Chinese public universities students experiences. International Journal of Social Science and Humanity, 3(6), 582-585.

Nor, M. R. M. (2011). Religious tolerance in Malaysia: An overview. Middle-East Journal of Scientific Research, 9(1), 23-27.

Peace, I. f. E. a. (2017) ). Global peace index 2017: measuring peace in a complex world St Leonards Institute for Economics \& Peace

Rahman, N. F. A., \& Khambali @ Hambali, K. M. (2013). Religious tolerance in Malaysia: Problems and challenges. International journal of Islamic thought, 3, 81-91.

Samad, Y. (2016). Peaceful co-existence in the light of Holy Qur'an: a case study of Christians living in Kuala Lumpur. (Doctoral thesis), University of Malaya, Kuala Lumpur. Retrieved from http://studentsrepo.um.edu.my/6935/1/THESIS 20_$2 \quad-$.pdf

Sintang, S. (2014). Peaceful co-existence in religious diversity in Sabah, Malaysia. Global Journal of Human-Social Science Research, 14(1). 
Sintang, S., Baharuddin, A., \& Khambali, K. M. (2012). Dialogue of life and its significance in inter-religious relation in Malaysia. International journal of Islamic thought, 2, 69-79.

Sultan Nazrin: respect religious boundaries to maintain peace and harmony. (June 12, 2014). Malay Mail Online Retrieved from http://www.themalaymailonline.com/malaysia/article/sultan-nazrin-respectreligious-boundaries-to-maintain-peace-and-harmony

Talib, A. T., Gill, S. S., \& Ramli, M. R. (2014). Pengaruh Agama Terhadap Identiti Politik: Kajian Kes Belia di Malaysia. Paper presented at the Seminar on National Resilience: Diversity in Creating Unity Premiera Hotel Kuala Lumpur.

Talib, A. T., Isa, N. A. M., S.Gill, S., Ahmad, Z., Jawan, J., \& Mohad, A. H. (2014 ). Persepsi terhadap toleransi sosio agama di Sabah dan Sarawak. Paper presented at the Seminar Antarabangsa Dakwah \& Etnik 2014: Da'wah \& Ethnicity: Multidisciplinary Perspective, Pusat Kajian Dakwah Orang Asli dan Pribumi, UKM, Bangi, Selangor. 